DOI: 10.36108/ujees/1202.30.0250

\title{
Determinants of Affordability in Rental Housing in Ogbomoso, Oyo State, Nigeria
}

\author{
Odunjo, O.O., Adeoye, D.O. and Oladimeji, S.B.
}

\begin{abstract}
This study assesses the determinants of affordability in rental housing in Ogbomoso, Southwest, Nigeria. The location was borne out of the fact that the city houses Ladoke Akintola University of Technology which is a source of employment. Ogbomoso North Local Government Area, the domiciled home of the University was purposively selected for the study. Random sampling was used in selecting two hundred and thirteen households. The questionnaire and observation formed the basic instruments for data collection which were administered to respondents to collect information on socioeconomic characteristics such as; house type and condition as well as house rent. Both descriptive and inferential statistical analyses were employed in the presentation of the findings; correlation analysis was used to test the relationship between households' income and house type. The bulk of the respondents collect $\$ 11,000-\$ 20,000(35.2 \%)$ indicating they are low-income workers, while the significant house type was Brazilian rooming house $(40.2 \%)$. Correlation analysis shows that there is a significant relationship between house type and households' income $(\mathrm{p}=0.030)$ indicating house type is a function of household income. The study suggests among others that, the income of residents should be factored into housing policies in Nigeria in determining the housing needs of people.
\end{abstract}

Keywords: Affordability, Determinants, Households' income, House type, Rental housing.

\section{Introduction}

Housing is one of the greatest problems confronting the developing nations generally and Nigeria in particular. It is not only a necessity of life; it has a pervasive impact on aspects of existence [1, 2]. Houses provide privacy and security against both physical and emotional intrusion. It is the principal focus of personal and family life and defines the community and access to jobs, services and other significant things in life. Affordability is the notion of reasonable costs in relation to income, that is housing that leaves households with sufficient income to meet other basic needs such as food, clothing, medical care, transport and education. It is also the ability of households to rent or purchase housing in an

Odunjo, O.O. and Adeoye, D.O. (Ladoke Akintola University
$\quad$ of Technology, Ogbomoso)
Oladimeji, S.B. (University of Ilorin, Ilorin)
Corresponding Author: ooodunjo@lautech.edu.ng
Phone Number: +2348034154340
Submitted:22-02-2021
Accepted:11-08-2021

area of choice at a reasonable price, the capacity to meet ongoing cost and the degree that discretionary income is available to achieve an acceptable standard of living [3]. Housing affordability is a key factor in determining a family's access to economic and educational opportunities, exposure to violence, environmental hazards and ability to accumulate financial assets.

The importance of affordability considerations goes much beyond the personal troubles experienced by individual households. According to [4], affordability has implications on employment, health, labour market, aged care, finance, community, sustainability and economic development. Thus, the problem of housing affordability is enormous and is a matter of great concern. It is present both in the rural and urban centres. In the urban centres, due to inconsistent government policies, inaccessibility to land and high cost of building materials, there have been problems in providing affordable shelter for the people. At 
the level of household, the problem of affordability could force a household down the housing ladder or indeed trap a household in a poor housing environment.

The housing problem basically relates to quantitative and qualitative housing needs in the developing countries in terms of high building costs, deficiency of housing finance arrangements, strict loan agreements and mortgages from banks etc [5]. Though there is a huge housing backlog, it is essential to identify the fact that people can only obtain what they can pay for. Housing affordability in this context can be described as the housing units that are affordable by that section of society whose income is below the median household income [6]. Thus, high costs of land, funding and building costs are responsible for increased prices of housing units. Increased prices of land have made it difficult to provide affordable housing in developing countries to low-income groups even in the cases when the government itself is part of development [7].

In Nigeria, housing problems manifest in overcrowding, growth of slums and the development of shanties in virtually every major city. The problems vary from inadequacy to the attendant impact on the psychological, social, environmental and cultural aspects. Housing is capital - intensive thus, the cost of adequate housing is beyond the reach of most Nigerians which bring the financial dimension of affordability. The challenges become not only to provide the houses but to make the houses affordable and convenient to the average citizen. It has been observed that the economic meltdown in the country has led to an upsurge in the standard of living thereby leaving little to pay for housing services; though, it has been established that Nigeria is one of the countries with the lowest Gross Domestic Product (GDP) in the world [8]. With increasing unemployment, the expenditure on housing services has made it seem "unaffordable" and explicit consideration has not been given to the need for justification in the affordability of housing services over the years.

In Ogbomoso, the establishment of Ladoke Akintola University of Technology (LAUTECH) had great impacts on the people in aspects such as employment generation, human resource development, capacity building and research development. Apart from the natural increase in population, there has been a larger influx of people into the town which is as a result of the attractions generated by the University thereby transforming to an increase in the demand for housing relative to shortages in supply. Thus, there is the need to pay attention to the impact of household income on the standard of living of the people. The study seeks to examine the relationship between households' income and house types in the area.

Ogbomoso is the second largest town in Oyo State after Ibadan and lies approximately $8^{0} 10^{1}$ North of the equator and $4^{0} 10^{1}$ East of the Greenwich meridian. The town lies within the derived savannah region and is a gateway to the northern part of Nigeria. It is 57 Kilometres to Ilorin, the capital of Kwara State and 104 Kilometres to Ibadan, the capital of Oyo State.

The town is a transitional zone between the rain forest and the savannah region and it is about 300 - 600 Metres above the sea level. Relief of the town is moderate with low forested hills and at times, steep-sided ridges arise abruptly from the surrounding country. There are lots of rivers in the town, among which are Alalubosa, Adunin, Kuye, Laka and Oba which flows southward and runs 5 Kilometres west of the town. Ogbomoso is made up of five local government areas which are Ogbomoso North and Ogbomoso south which constitute the township. Others are Orire, Ogo Oluwa and Surulere. 


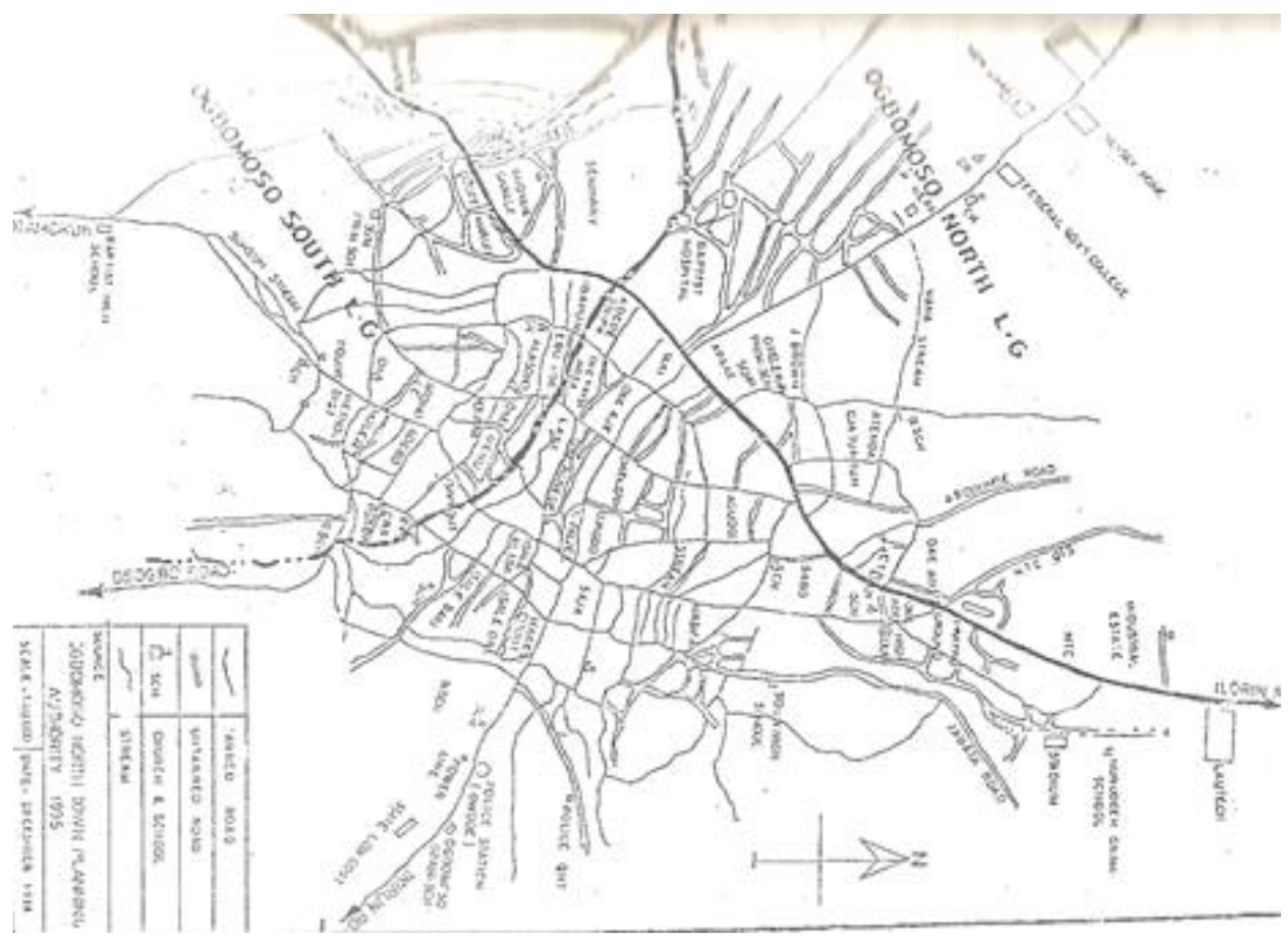

Figure 1: Map of Ogbomoso

Ladoke Akintola University of Technology was created in 1990 and is located in Ogbomoso North local government area of the town. The 1991 population census figure for Ogbomoso North local government area was seventyseven thousand, two hundred and forty-nine $(77,249)$, while the projected population for 2011 is one hundred and sixty-nine thousand, one hundred and seventy-one $(169,171)$.

\section{Materials and Methods}

Both primary and secondary data were used for the research. Primary data collection involved first-hand information on the problem from the field through the use of structured questionnaires and observation in order to provide a comprehensive explanation of the subject of investigation thereby increasing trust in the validity of the research findings and conclusion. Secondary data involved a review of literature from books and journals as well as consultation of the National Population Commission (NPC) to obtain the population figure of the study area. Ogbomoso North
Local Planning Authority was also visited for a map of the study area.

The questionnaire was designed to extract relevant information from the rental households. Households' survey includes the socioeconomic characteristics of respondents, house types and conditions as well as house rent. The study was limited to Ogbomoso North Local Government, the seat of LAUTECH (Figure 1). The local government area comprises ten geopolitical wards (Table 1).

However, due to lack of detailed population census data in the Local Government Area, there was an inability to get population data at the political ward level for 2020; hence, the projected 2011 population census data was utilized as the basis, since the aim of the research is not to use the actual population, but to get a sample size that is representative of the population. The sample size used for the household questionnaire was $0.7 \%$ since the local government was highly populated and this provided the corresponding number of 
questionnaires administered in each political ward. A total of two hundred and thirteen structured questionnaires were thus distributed to households and a total of one hundred and ninety-nine were retrieved. The household's population was the targeted population and was calculated by dividing the total population of each ward by six. This was based on the assumption that an average family household in the study area consists of six persons, the parents and four children. The questionnaires were administered using a random sampling method to households to ensure all wards are covered and a fair representation of the population elements in respect to the proportion bore to the parent population (Table 1).

Table 1: Population Projection and Sample Size

\begin{tabular}{|c|c|c|c|c|}
\hline Ward & $\begin{array}{c}1991 \\
\text { Popula } \\
\text { tion }\end{array}$ & $\begin{array}{c}2011 \\
\text { projec } \\
\text { tion } \\
(4 \%) \\
\end{array}$ & $\begin{array}{c}\text { Numbe } \\
\text { r of } \\
\text { Househ } \\
\text { olds }\end{array}$ & $\begin{array}{c}\text { Number } \\
\text { of } \\
\text { Question } \\
\text { naire }\end{array}$ \\
\hline $\begin{array}{l}\text { Abogu } \\
\text { nde }\end{array}$ & 9,227 & 20,207 & 3,367 & 27 \\
\hline $\begin{array}{l}\text { Aje - } \\
\text { Ogunb } \\
\text { ado }\end{array}$ & 8,647 & 18,936 & 3,156 & 19 \\
\hline $\begin{array}{l}\text { Aguod } \\
\text { o - } \\
\text { Masifa }\end{array}$ & 7,496 & 16,416 & 2,736 & 19 \\
\hline $\begin{array}{l}\text { Islae - } \\
\text { Afon }\end{array}$ & 5,774 & 12,645 & 2,107 & 15 \\
\hline Alaasa & 8,064 & 17,660 & 2,943 & 21 \\
\hline $\begin{array}{l}\text { Saja/Is } \\
\text { ale Ora }\end{array}$ & 8,078 & 17,690 & 2,948 & 20 \\
\hline Jagun & 9,187 & 20,119 & 3,352 & 24 \\
\hline $\begin{array}{l}\text { Okeler } \\
\text { in }\end{array}$ & 7,530 & 16,490 & 2,748 & 19 \\
\hline Osupa & 7,481 & 16,312 & 2,730 & 26 \\
\hline $\begin{array}{l}\text { Sabo/ } \\
\text { Tara }\end{array}$ & 5,765 & 62583 & 2,104 & 23 \\
\hline Total & 77,249 & 169,171 & 28,191 & 213 \\
\hline
\end{tabular}

Source: Author's field work (2020)

Thus, housing was represented by house typology and the data obtained were analysed by descriptive and inferential statistical analyses. The descriptive statistics used were frequency counts and percentages, while correlation analysis was used to test the relationship between households' income and house types.

\section{Results and Discussion}

\section{A. Socioeconomic Characteristics of Respondents}

About one-fifth $(20.0 \%)$ of the population of the respondents were below 25 years old. This was followed by those that were $26-35$ years (43.2\%), while $36-45$ years account for $11.6 \%$. $46-55$ and above 55 years were $12.1 \%$ and $12.6 \%$ respectively. The implication of this is that the bulk of the respondents were $26-35$ years whose opinions were adequately represented. They are thus, the active youths who drive innovations in national, regional and local workforces.

More than two-fifths (46.2\%) were married which confirms the submission of $[1,9,10]$ that the bulk of a set population is married. Also, more than two-fifths $(42.2 \%)$ were single, while divorced and widowed respondents account for $4.0 \%$ and $7.0 \%$ respectively (Table 2). $51.3 \%$ of the sampled respondents were male, while $48.2 \%$ were female. Thus, the inference drawn is that majority of the sampled respondents were male and are likely to have dominated opinion in the study of affordability than females in the area. More so, males are often perceived as the dominant household head that is always responsible for various family/housing expenses.

On the other hand, $36.7 \%$ of respondents had a secondary school leaving certificate, while more than two fifths $(45.7 \%)$ possessed a tertiary school certificate. Respondents with no formal education constituted $5.5 \%$ with only $12.1 \%$ having primary education. The implication of this finding is that majority of the respondents have formal education up to the minimum standard required by the Federal government in Nigeria constitution. Furthermore, Christianity (50.0\%) was mostly practised in the area, followed by Islam 
(45.2\%), while traditional religion was $4.0 \%$. Thus, the inference drawn is that every religion was adequately represented and opinion covered every religious organization.

Trading $(35.2 \%)$ dominated the main economic activities of the people, while $21.6 \%$ were teachers, with $7.6 \%$ being civil servants. However, $16.6 \%$ were farmers, while $8.0 \%$ were students. Thus, the implication of this is that traders, civil servants and teachers characterized the victim of housing affordability consequences in the area. Also, the highest household income was $\$ 11,000$ $\$ 20,000 \quad(35.2 \%)$ followed by $\$ 21,000-$ $\$ 30,000(15.6 \%), \$ 41,000-\$ 50,000(13.1 \%)$, below $\$ 10,000$ (19.1\%), $\$ 31,000-\$ 40,000$ $(9.0 \%)$ and above $\$ 50,000$ (6.5\%). The inference drawn is that they are low-income workers by Nigeria standard $[1,8]$.

Five types of houses were identified in the area. These are compound house, Brazilian rooming house (Tenement or face - me - I - face you), detached house, flat and self-contained. More than two fifths $(40.2 \%)$ of the respondents lived in Brazilian rooming houses. This was followed by $19.1 \%$ living in flat houses and $16.6 \%$ compound houses. The inference drawn is that majority of the inhabitants of the area lived in old-style Brazilian and compound houses, some of which are characterised by shared facilities, poor location and absence of facilities like kitchen, toilet, bathroom, dining, and store accompanied with a poor rooming arrangement. This opposed the submission of $[1,11,12]$ that in Nigeria, people prefer the flat building for privacy reasons. Only $14.6 \%$ lived in detached houses, while self-contained accounts for $9.5 \%$.

Table 2: Socioeconomic Characteristics

\begin{tabular}{llcc}
\hline S/N & Variable & $\begin{array}{l}\text { Frequency } \\
\text { (N) }\end{array}$ & $\begin{array}{l}\text { Percentage } \\
\text { (\%) }\end{array}$ \\
\hline a. & Age (Years) & & \\
& (i) less than 25 & 41 & 20.6 \\
& (ii) $26-35$ & 86 & 43.2 \\
\hline
\end{tabular}

\begin{tabular}{|c|c|c|c|}
\hline \multirow{7}{*}{ b. } & (iii) $36-45$ & 23 & 11.6 \\
\hline & (iv) $46-55$ & 24 & 12.1 \\
\hline & (v) Above 55 & 25 & 12.6 \\
\hline & \multicolumn{3}{|l|}{ Gender } \\
\hline & (i) Male & 102 & 51.3 \\
\hline & (ii) Female & 96 & 48.2 \\
\hline & (iii)No & 1 & 1 \\
\hline \multirow{6}{*}{ c. } & \multicolumn{3}{|l|}{ Marital Status } \\
\hline & (i) Single & 84 & 42.2 \\
\hline & (ii) Married & 92 & 46.2 \\
\hline & (iii) Divorced & 8 & 4.0 \\
\hline & (iv) Widowed & 14 & 7.0 \\
\hline & (v) $\quad$ No & 1 & 0.6 \\
\hline \multirow[t]{5}{*}{ d. } & \multicolumn{3}{|c|}{ Educational Status } \\
\hline & $\begin{array}{l}\text { (i) No formal } \\
\text { education }\end{array}$ & 11 & 5.5 \\
\hline & education & 24 & 12.1 \\
\hline & $\begin{array}{l}\text { (iii) Secondary } \\
\text { education }\end{array}$ & 73 & 36.7 \\
\hline & (iv) Tertiary & education & 45.7 \\
\hline \multirow[t]{5}{*}{ e. } & \multicolumn{3}{|c|}{ Religious Background } \\
\hline & (i) Christianity & 100 & 50.3 \\
\hline & (ii) Islam & 90 & 45.2 \\
\hline & (iii) Traditional & 8 & 4.0 \\
\hline & (iv) Others & 1 & 0.5 \\
\hline \multirow[t]{7}{*}{ f. } & \multicolumn{3}{|l|}{ Occupation } \\
\hline & (i) Farming & 33 & 16.6 \\
\hline & (ii) Trading & 70 & 35.2 \\
\hline & $\begin{array}{l}\text { (iii)Civil } \\
\text { servant }\end{array}$ & 43 & 21.6 \\
\hline & (iv) Student & 35 & 17.6 \\
\hline & (v) Others & 16 & 8.0 \\
\hline & & 2 & 1.0 \\
\hline \multirow[t]{6}{*}{ g. } & \multicolumn{3}{|l|}{ Household size } \\
\hline & (i) $1-2$ persons & 30 & 15.0 \\
\hline & $\begin{array}{l}\text { (ii) } 3-4 \\
\text { persons }\end{array}$ & 52 & 26.1 \\
\hline & $\begin{array}{ll}\text { (iii) } 5-6 & -6 \\
\text { persons } & \end{array}$ & 65 & 32.7 \\
\hline & $\begin{array}{ll}\text { (iv) } 7 & - \\
\text { persons } & \end{array}$ & 20 & 10.1 \\
\hline & $\begin{array}{l}\text { (v) Above } 8 \\
\text { persons }\end{array}$ & 32 & 16.1 \\
\hline \multirow[t]{8}{*}{ h. } & \multicolumn{3}{|c|}{ Household Income } \\
\hline & 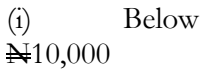 & 38 & 19.1 \\
\hline & $\begin{array}{l}\text { (ii) } \$ 11,000- \\
\approx 20,000\end{array}$ & 70 & 35.2 \\
\hline & $\begin{array}{l}\text { (iii) } 21,000- \\
¥ 30,000\end{array}$ & 31 & 15.6 \\
\hline & $\begin{array}{l}\text { (iv) } ¥ 31,000- \\
¥ 40,000\end{array}$ & 18 & 9.0 \\
\hline & $\begin{array}{l}\text { (v) } \$ 41,000- \\
\$ 50,000\end{array}$ & 26 & 13.1 \\
\hline & $\begin{array}{l}\text { (vi) Above } \\
\$ 50,000\end{array}$ & 13 & 6.5 \\
\hline & $\begin{array}{ll}\text { (vii) } & \text { No } \\
\text { Response } & \end{array}$ & 3 & 1.5 \\
\hline \multirow[t]{4}{*}{ i. } & \multicolumn{3}{|c|}{ Length of Stay in the area } \\
\hline & (i) $1-5$ years & 105 & 52.8 \\
\hline & (ii) $6-10$ years & 48 & 24.1 \\
\hline & $\begin{array}{l}\text { (iii) } 11-15 \\
\text { years }\end{array}$ & 19 & 9.5 \\
\hline
\end{tabular}




\begin{tabular}{llcc}
\hline & $\begin{array}{l}\text { (iv) Above 20 } \\
\text { years }\end{array}$ & 13 & 6.5 \\
j. & \multicolumn{1}{c}{ Nativity } & & 7 \\
& $\begin{array}{l}\text { (i) Ogbomoso } \\
\text { (ii) No-indigene }\end{array}$ & 113 & 56.8 \\
& $\begin{array}{l}\text { (iii) No } \\
\text { response }\end{array}$ \\
Total & $\mathbf{1 9 9}$ & 42.2 \\
& & $\mathbf{1 0 0 . 0}$
\end{tabular}

Source: Author's field survey (2020)House Type and Condition

However, ownership type indicates that private sector housing was $63.3 \%$, government accounts for $7.5 \%$, the family house was $26.9 \%$, while cooperative housing was $2.5 \%$. Thus, private sector or individual housing was the major form of house ownership in the area, and there was little government intervention in the provision of residential housing for the people. Half $(50.8 \%)$ of the houses were between 11 and 20 years old, followed by those that were $21-30$ years $(22.6 \%)$, less than 10 years old constitute $7.5 \%$. The implication of this is that the average of the houses in the area was above 10 years. Thus, they are relatively sound, not liable to depreciation, dilapidation and structural weaknesses.

Furthermore, number of rooms occupied by respondents ranged from 2 rooms (19.1\%), 1 room (24.6\%), 3 rooms (14.1\%), 4 rooms (9.5\% and above 4 rooms $(22.6 \%)$. In relation to household size, most households had access to $1-2$ rooms which is not convenient for their activities. Also, a total number of persons per house revealed less than 4 persons $(27.1 \%)$, 4 - 6 persons $(25.1 \%)$ and more than 10 persons $(12.6 \%)$ characterized the houses. Thus, it implies that $4-6$ persons are the dominant number of persons per house in the area.

However, the condition of houses revealed that houses were without any defect $(31.7 \%)$, with internal defects only (14.6\%), with external defects only $(31.2 \%)$ and with both internal and external defects $(20.5 \%)$ (Table 3). The inference drawn is that only three-tenths of houses in the area are sound and without defects and that houses are prone to defects due to intensive use. Also, 28.1\% of the buildings had pit latrines, $59.2 \%$ made use of water closet systems, while $12.6 \%$ used community dumping grounds and nearby bushes. This implies that considerable proportions of houses in the area had convenient and sanitary modern toilet systems. $77.9 \%$ of houses had bathrooms, while $18.6 \%$ did not have and had their bath in open places or temporary bathrooms fixed to the back of the houses. A significant proportion of $67.1 \%$ of houses had a kitchen, while $32.9 \%$ were without a kitchen.

The monthly rent paid by respondents ranged from $\$ 1,000$ - $\$ 3000$ (19.1\%), less than $\$ 1,000(19.6 \%), \$ 3,001-\$ 5,000(6.5 \%)$ and above $\$ 5,000(47.7 \%)$. The implication of this is that the bulk of the respondents pay more than $\$ 5,000$ as rent every month.

Table 3: House types and Condition

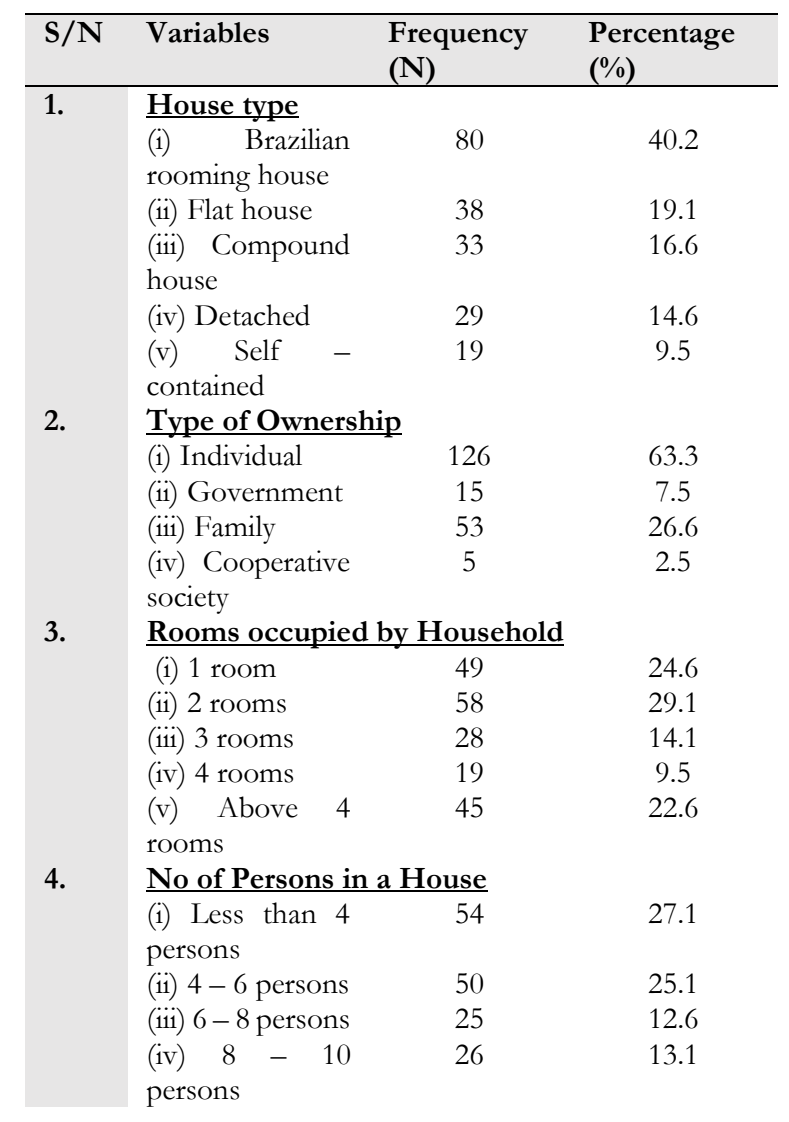




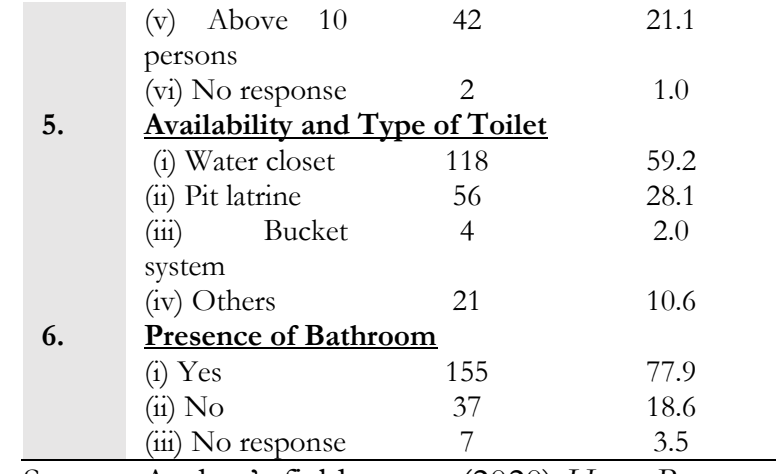

Source: Author's field survey (2020) House Rent

Table 4: Rent per Month

\begin{tabular}{lcc}
\hline $\begin{array}{l}\text { Variables } \\
\text { Monthly Rent per }\end{array}$ & $\begin{array}{l}\text { Frequency } \\
\text { (N) }\end{array}$ & $\begin{array}{l}\text { Percentage } \\
\text { (\%) }\end{array}$ \\
Room & & \\
\hline (i) Less than $\$ 1,000$ & 39 & 19.6 \\
(ii) $¥ 1,000-\$ 3,000$ & 38 & 19.1 \\
(iii) $¥ 3,001-\$ 5,000$ & 13 & 6.5 \\
(iv) Above 5,000 & 95 & 47.7 \\
Total & 199 & 100 \\
\hline
\end{tabular}

Source: Author's field survey (2020)

Table 5: Type of Room Occupied by Respondents

\begin{tabular}{|c|c|c|c|c|c|c|c|c|c|}
\hline \multirow[t]{2}{*}{$\begin{array}{l}\text { S/ } \\
\text { N }\end{array}$} & \multirow[t]{2}{*}{ Type } & \multicolumn{2}{|c|}{$\begin{array}{c}\text { Availabl } \\
\text { e }\end{array}$} & \multicolumn{2}{|c|}{$\begin{array}{c}\text { No } \\
\text { available }\end{array}$} & \multicolumn{2}{|c|}{$\begin{array}{l}\text { No } \\
\text { respons } \\
\text { e }\end{array}$} & \multicolumn{2}{|c|}{ Total } \\
\hline & & $\mathbf{N}$ & $\%$ & $\mathbf{N}$ & $\%$ & $\mathbf{N}$ & $\%$ & $\mathbf{N}$ & $\%$ \\
\hline 1. & Sitting & 11 & 57. & 71 & 35. & 1 & 6. & 19 & 10 \\
\hline & room & 5 & 8 & 11 & 7 & 3 & 5 & 9 & 0 \\
\hline 2. & Bedroo & 17 & 87 & 16 & 8.0 & 1 & 5. & 19 & 10 \\
\hline 3. & $\begin{array}{l}\text { Dining } \\
\text { room }\end{array}$ & 52 & $\begin{array}{c}26 . \\
1\end{array}$ & $\begin{array}{c}13 \\
1\end{array}$ & $\begin{array}{r}65 . \\
8\end{array}$ & $\begin{array}{l}1 \\
6\end{array}$ & 8 & $\begin{array}{c}19 \\
9\end{array}$ & $\begin{array}{c}10 \\
0\end{array}$ \\
\hline 4. & Store & 90 & $\begin{array}{c}45 . \\
2\end{array}$ & 93 & $\begin{array}{c}46 . \\
7\end{array}$ & $\begin{array}{l}1 \\
6\end{array}$ & 8 & $\begin{array}{c}19 \\
9\end{array}$ & $\begin{array}{c}10 \\
0\end{array}$ \\
\hline 5. & $\begin{array}{l}\text { Kitche } \\
\mathrm{n}\end{array}$ & $\begin{array}{c}16 \\
3\end{array}$ & $\begin{array}{c}81 . \\
9\end{array}$ & 35 & $\begin{array}{c}17 . \\
6\end{array}$ & 0 & 0 & $\begin{array}{c}19 \\
9\end{array}$ & $\begin{array}{c}10 \\
0\end{array}$ \\
\hline
\end{tabular}

Source: Author's field survey (2018)

However, when this is related to the spaces available in the houses (type of room), there were sitting room $(57.8 \%)$, bedroom $(87.0 \%)$, dining room $(26.1 \%)$, store $(45.2 \%)$ and kitchen $(81.9 \%)$. The inference drawn from this is that majority of houses in the area do not have a dining room and hence, used the sitting room/bedroom as dining. Thus, the houses are inhabited by low-income workers whose house rent is directly proportional to the monthly income.
Husband accounts for 58.3\% of responsibilities of house rent payment, wife was $30.6 \%$, while other members of the family account for $10.1 \%$. This should be expected as the husband is believed to be the head of the family and breadwinner in any Nigerian society. The fact that wives share a significant proportion of house rent could be attributed to low wages and salaries and men's inability to afford the burden of houses expenses and other family basic needs.

Furthermore, as emphasized by contemporary literature that most households in the developing nations do experience difficulties with basic family expenses in the payment of housing expenses, $58.8 \%$ experience difficulties while paying house rents, while $41.2 \%$ do not experience any difficulty with family expenses. Thus, the monthly income of average households in the area is not enough to cater for other family basic expenses after the payment of housing related expenses. Housing seems not to be affordable for an average family in the area.

In terms of source of money for payment of house rent, 54.8\% pay housing expenses from cooperative societies as they belong to 1 or 2 cooperative societies, $18.6 \%$ depend on salary/income, borrowing institution was $10.0 \%$ while other sources such as savings, gift and inheritance account for $16.6 \%$.

\section{B. Relationship between Households' Income and House Type}

Table 6 shows a correlation analysis showing the relationship between households' income and house type in the study area. With a correlation coefficient $r=0.720$, it is observed that there is a very high positive correlation between households' income and house type in the study area. Also, with p-value of 0.000 , it is observed that the correlation is significant at 0 , 01 level i.e. $\mathrm{p}<0.01=0.000$ confidence interval. 
The implication of this is that the higher the income, the better the choice of house.

Table 6: Effects of Households' Income on House Type

\begin{tabular}{llcc}
\hline & & $\begin{array}{l}\text { Households' } \\
\text { Income }\end{array}$ & $\begin{array}{l}\text { House } \\
\text { type }\end{array}$ \\
\hline $\begin{array}{l}\text { Households' } \\
\text { income }\end{array}$ & $\begin{array}{l}\text { Pearson } \\
\text { correlation } \\
\text { significant }\end{array}$ & 1 & 0720 \\
& $\begin{array}{l}\text { (2 tailed) } \\
\text { House type }\end{array}$ & 213 & 0.000 \\
& $\mathrm{~N}$ & & 213 \\
& $\begin{array}{l}\text { Pearson } \\
\text { correlation }\end{array}$ & 0.720 & 1 \\
& $\begin{array}{l}\text { sig. } \\
\text { tailed) }\end{array}$ & 213 & 213 \\
& $\mathrm{~N}$ & & \\
\hline
\end{tabular}

Correlation is significant at the 0.01 level (2 tailed) Source: Author's field survey (2020)

The choice of house occupied by households is a function of income and financial capacity. Thus, the house occupied is determined by the income of the household.

\section{Conclusion}

This study has shown the determinants of affordability in rental housing in Ogbomoso, South-west Nigeria. It has discussed the socioeconomic characteristics of residents in relation to the characteristics of houses being occupied. As exemplified in the study, people stay in different kinds of houses such as Brazilian rooming houses, flat houses, compound houses, self - contain and detached houses and cooperative societies emerged as the most prevalent source of housing expenses in the area. Also, income plays a significant factor in determining the type of house being occupied. There is thus, the need to factor the income of residents into housing policy in Nigeria in determining the housing needs of people. This will go a long way in arriving at the types of houses that can be afforded taking into cognizance the household size. Housing policies in the country are not successful because the target people are not articulated, before the standard; almost stereotype designs that have no relation to the immediate socioeconomic background and cultural environment are adopted.

Also, there is the need to reinvigorate the use of cooperative societies as a means of financial empowerment of the citizenry in Nigeria. Citizens need to be encouraged to join a cooperative society and more cooperative societies should be allowed to blossom and adequately monitored to enhance their capacity to provide more loans for disbursement and logistics for housing provision to members.

\section{References}

[1] Odunjo, O.O. "Housing Finance Strategies and Design Characteristics in the Urban Fringe of Ibadan, Southwest, Nigeria", Unpublished Ph.D Thesis, Ladoke Akintola University of Technology, Ogbomoso, 2014.

[2] Ajayi, M., Nwosu, A. and Ajani, Y. "Students' Satisfaction with Hostel Facilities in Federal University of Technology, Akure, Nigeria", European Scientific Journal, vol. 11, no. 34, 2015.

[3] Mullner, E.M. "Austerity and Reform to Affordable Housing Policy", Journal of Housing and the Built Environment. vol. 28, 2013, pp. 397-407.

[4] Gabriel M., Jacobs, K., Arthurson, K., Burke, T. and Yates, J. "Conceptualizing and Measuring Affordability Problem”, 2005.

[5] Fingleton, B. "Housing Supply, Housing Demand and Affordability", Urban Studies, vol. 45, no. 8, 2008, pp. 1545-1563.

[6] Makinde, O.O. "Housing Delivery System, Need and Demand", Environment, Development and Sustainability. vol. 16, no. 1, 2014, pp. 49-69.

[7] Fariha, T., Muhammad, S., Javeria, H., Zumaira, Z., Sana, M., Areesha, G., Minahil, N. and Nida, S. "Developing Countries Perspective on Housing Affordability: Recommendations for Pakistan", Technical Journal, University of Engineering and Technology (UET) Taxila, Pakistan. ISSN:18131786 (Print) 2313-7770 (Online), 2018. 
[8] Odunjo, O.O., Okanlawon, S.A. and Ayinla, A.K. "Evaluation of Housing Quality in the Urban Fringe of Ibadan, Southwest, Nigeria", TETfund Research Grant Report, LAUTECH, Ogbomoso, 2015.

[9] "Statistics South Africa", Gender Statistics in South Africa, 2011, pp. 5.

[10] Odunjo, O.O., Okanlawon, S.A., Ayinla, A.K., and Ayanda, O.O.L. "Socio - Economic Correlates of House Typology in Ibadan, South west, Nigeria", Ibadan Planning Journal, Department of Urban and Regional Planning, University of Ibadan, Ibadan, 2015, pp. $105-124$.

[11] Aribigbola, A. "Conceptual Issues in Housing and Housing Provision in Nigeria: In: Akinbamijo Olumuyiwa Bayo, Fawehinmi Abayomi Stevens, Ogunsemi Deji Rufus and Olotuah Abiodun (eds.)", Effective Housing in the 21st Century Nigeria. AKT Ventures Limited, 2000, pp. 1.

[12] Aribigbola, A. "Housing Affordability as a Factor in the Creation of Sustainable Environment in Developing World: The Example of Akure, Nigeria", Journal of Human Ecology, vol. 35, no. 2, 2011. 